\title{
Critical Discourse Analysis of Asian Games 2018's Preparation in Indonesia Online News Media
}

\author{
Teguh Dwi Putranto \\ Communication and Media Studies \\ Airlangga University \\ Surabaya, Indonesia \\ teguhputranto89@gmail.com
}

\author{
Daniel Susilo \\ PhD Program in Social Sciences \\ Airlangga University \\ Surabaya, Indonesia
}

\begin{abstract}
Asian Games as the highest sports event in the Asian continent became a prestigious sporting event, especially for countries in Asia. As one of the countries in the continent of Asia, Indonesia has a pretty onerous task in the Asian Games this year. In addition to having to perform optimally as a contingent that competes, Indonesia also get a big task as host of the 2018 Asian Games. In this study, the authors use a qualitative approach. Also, the authors want to see how far the preparation of Indonesia is preparing to host the 2018 Asian Games through online news reported by tribunnews.com by using critical discourse analysis Van Dijk.
\end{abstract}

Keywords-asian games; CDA; news media; online; preparation

\section{INTRODUCTION}

This article would to describing how the online news media make construction and discourse about the preparation of the Asian's biggest Sports event in 2018, Asian Games XVIII, Jakarta.

The Asian Games is the most prestigious event organised by the Olympic Council of Asia. Similar to the Olympic Games, the Asian Games are held every four years, with the 17th edition to be held in Incheon in 2014 [1].

The Asian Games follow the sports programme of the Olympic Games, with swimming and athletics as the core sports, as well as featuring disciplines which reflect the diverse sporting culture of the continent such as sepaktakraw (South East Asia), kabaddi (South Asia) and wushu (East Asia) [1].

Asian Games is the biggest sports event in continental Asia which is held every 4 years. Indonesia as one of the countries in the Asian continent became one of the countries that are active in the participation of the Asian Games.

And at the 18th Asian Games in 2018, Indonesia had the opportunity to host the second time that Indonesia last hosted in 1962. Thailand became the most host country of the 4th Asian Games, 1966, 1970, 1978 and last 1998.

Talking of the overall champion, Japan became the first country to become the most successful country in the implementation of Asian Games I to the Asian Games to VIII. After that Japan's position as the overall champion was replaced by China from Asian Games to IX until Asian Games to XVII.

This is of course not only a double burden for Indonesia in particular in the organization of the Asian Games. Whereas the contingent, Indonesia should be able to perform as much as possible to get a lot of medals in the sports that followed, but on the other hand Indonesia must also host a great event that serves its guests well.

Surely this will be a great job for the host of any sporting event because the failure or success of the host will be a headline around the world. Because success or failure is subjective then it is difficult to conclude the meaning of an event's success.

\section{RESEARCH METHOD}

This research is a qualitative research that uses a critical approach in dismantling the structure of discourse in the text. Researchers use Critical Discourse Analysis to delve deeper into hidden meanings, disassemble concepts and to understand how interests are in the production process of discourse.

Discourse Analysis according to Paltridge is a study that focuses on knowledge (Knowledge) about words, clauses, phrases, and sentences needed for communication to run effectively [2]. In further developments, Van Dijk considered that Discourse Analysis as a method of seeing how the structures in the text have the power to discourse a representation as well as the ideology behind the text [3].

Van Dijk Discourse Analysis Model, according to Astuti involves three structures namely: text, social cognition, and societal (social) [4]. The method used in this research is trying to reveal the discourse that exists in the media through Critical Discourse Analysis proposed by Van Dijk.

The unit of analysis in this study is the signs in the form of text on the online news in the portal www.tribunnews.com seen from the vocabulary, semantics and sentence contained in the news that contains topics about preparation of the Asian's biggest Sports event in 2018, Asian Games XVIII, Jakarta.

Tribunnews.com was chosen as the unit of analysis in this study because based on website survey according to Alexa.com ranking website (http://www.alexa.com/topsites/countries/ID), 
tribunnews.com ranked 4th globally and is in 1st rank for the online portal from Indonesia.

\section{RESULTS AND DISCUSSION}

On the Article posted on the page: http://www.tribunnews.com/sport/2017/02/20/puan-maharanirequest-all-focus-to-preference-asian-games-2018.

Redaksi Tribunnews memberikan judul Puan Maharani Minta Semua Fokus ke Persiapan Asian Games 2018. Tribunnews Editorial titled Puan Maharani Asked All Focus on 2018 Asian Games Preparation [5].

The title was made by affirming the figure of Puan Maharani as Coordinating minister in charge of sports giving a reminder that the Asian Games will be held in approximately one year more (news written on 20 February 2017).

This news started news leads with the statement that the ranks of Menpora held a special coordination meeting on the 2018 Asian Games celebration.

Usai rapat, Puan Maharani mengatakan, rapat koordinasi tingkat menteri hari ini berkaitan dengan progres penyelenggaraan Asian Games XVIII tahun 2018. Penyelenggaraan Asian Games XVIII diperlukan berbagai kesiapan agar pelaksanaan berlangsung sukses penyelenggaran, sukses prestasi dan sukses pemberdayaan ekonomi. After the meeting, Puan Maharani said the ministerial coordination meeting today is related to the progress of hosting the XVIII Asian Games in 2018. The organization of the Asian Games XVIII required various readiness for successful implementation of successful, successful and successful economic empowerment [5].

In the third paragraph, the emphasis on Puan Maharani as the minister who will be responsible for the success of the 2018 Asian Games is shown by repeating the word "success" three times. The first success was the successful implementation, where Puan Maharani was discouraged as a minister who demanded all his subordinates to guarantee the success of the activities of the activities. The second success is a successful achievement, the use of the word affirms that Minister Puan demands that Indonesian athletes competing in the 2018 Asian Games also must win to ensure that success. While the third success used in the news is a successful economic empowerment that stressed that the minister Puan demanded the 2018 Asian Games in Indonesia should produce economic impact for Indonesia.

The structure used in this news is a path in the view of Minister Puan as central in the organization of the 2018 Asian Games. The non-coordinating ministers are described reporting on the progress of the preparation of the Asian Games by detailing the names of the ministers, and by being subordinated by Puan Maharani.

In general, this message is preparing the preparations for the 2018 Asian Games to come from a command centered on Puan Maharani as Coordinating Minister who also oversees sports. Despite discussions about the lack of coordination between ministers and regional governors of the 2018 Asian Games, Puan Maharani became the central point not only on the use of his name in the headlines alone but researchers found 8 times the name of Puan Maharani used in the news flow.

In his capacity as Coordinating Minister instead of a minister who is technically in charge of Sports, this news should not focus on the figure of characterizing Puan Maharani but focuses on how details of the preparations for the 2018 Asian Games.

A more or less similar emphasis also appears on the news on the page: http://www.tribunnews.com/national/2017/04/17/menko-pmkprogres-ppt-asian-games-2018-signs-target. This news aired two months from the first news.

This news uses the title: Coordinating Minister for Political and Security Affairs: Progress of 2018 Asian Games Preparation Targeted. Menko PMK: Progres Persiapan Asian Games 2018 Sesuai Target [6].

Similar to the first news, this news uses the title by displaying the figure of Puan Maharani as Coordinating Minister. With the use of news leads: Preparation of Indonesia to host the 2018 Asian Games continues to be established. This news uses a single sentence as its news lead as an affirmation that the preparation of the Asian Games preparation continues. In the second paragraph, the point of view of the news again focused on the figure of Puan Maharani with the affirmation that progress in preparation of Asian games 2018. The word progress is used to show positive news tone on the figure of Puan Maharani.

In this second news re-exposure of preparatory data in the perspective of Puan Maharani elaborated with the proportion of more than $80 \%$ of the total texts. This emphasis confirms that the 2018 Asian Games is centered on Coordinating Minister for Culture, Puan Maharani, not too technical ministers such as Kemenpora.

In other news reports, there was also a comparison where negative tone - tones were labeled to the figure of the Minister of Technical Affairs such as the Minister of Youth and Sports. Lack of facilities and not ready athlete homesteads are charged with a responsibility of kemenpora, not associated with Minister Puan Maharani.

\section{CONCLUSION}

There has been a cult of a person in this case is Puan Maharani. Her position as coordinator minister was preached with exaggeration. Errors or deficiencies in the preparation of games asian labeled on the technical ministry (Menpora). While Puan Maharani is positioned as minister of salvation in preparation for asian games.

\section{ACKNOWLEDGMENT}

In this paper, the research was sponsored by the Indonesian Endowment Fund for Education, Ministry of Finance, Republic Indonesia. 


\section{REFERENCES}

[1] www.okasia.org http://www.ocasia.org/Game/GamesL1.aspx?9QoyD9QEWPeJ2ChZBk 5 tvA $==$

[2] B. Paltridge, Discourse analysis: An introduction. London: Continuu, 2006.

[3] T.A. Van Dijk, Principles of Discourse Analysis. London : Sage, 1993
[4] S.I. Astuti, Program Sahur Ramadhan di TV : Analisis Wacana Kristis. in Deddy Mulyana et, all. (Eds.), Metode Penelitian Komunikasi. Bandung: Rosda, 2007.

[5] http://www.tribunnews.com/ http://www.tribunnewa.com/sport/2017/02/20/puan-maharani-mintasemua-fokus-ke-persiapan-asian-games-2018

[6] http://www.tribunnews.com/

http://www.tribunnews.com/national/2017/04/17/menko-pmk-progresppt-asian-games-2018-signs-target 